日臨外会誌 $63(3), 755-758,2002$

症例

大腿神経麻瘴をきたした S 状結腸秝室穿孔による後腹膜膿瘍の 1 例

岡崎市民病院外科

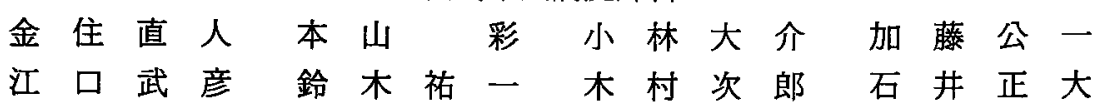

大腿神経麻㾇をきたした $\mathrm{S}$ 状結腸䕀室穿孔による後腹膜膿場の稀な 1 例を経験した ので報告する. 症例は69歳, 女性. 主訴は, 発熱, 左側腹部痛, 歩行障害. 腹部 CTに て, 左骨盤側壁に径約 $4 \mathrm{~cm}$ 大て S 状結腸に接し内部に液体と空気による鏡面を形成す る襄胞性腫瘤を認めた.S 状結腸息室穿孔による後腹膜膿場と診断し, 緊急手術を施行し た. S 状結腸は骨盤左側壁と炎症性に癒着しており，周囲は著明に浮腫状であった. S 状 結腸を遊離すると多量の膿汁の流出を認めた. S 状結腸切除術, ドレナージ術を施行し た. なお, 炎症が高度のため covering colostomy を造設した。摘出標本て S 状結腸馝室 穿孔による後腹膜膿瘍と診断された。術後は，速やかに歩行障害は改善した，大腸息室 の後腹膜穿孔は比較的稀である. また, 大腸穿孔による後腹膜膿瘍が大腿神経麻瘏を合 併した症例は, 調べ得た範囲内で本邦 2 例目であった。

索引用語：後腹膜膿瘍, 大腿神経麻㾝, 大腸蒩室穿孔

緒言

近年, 大腸息室炎による大腸穿孔の報告例は增加し ている. 今回われわれは，歩行障害（大韨神経麻缯） を呈した S 状結腸媳室穿孔による後腹膜膿場の 1 例 を経験したので,若干の文献的考察を加えて報告する。

\section{症例}

患者：69歳，女性.

主訴：左側腹部痛, 発熱, 歩行障害.

家族歴：特記すべきことなし.

既往歴: 肝炎 (28歳), 子宮外妊娠 (29歳), 糖尿病 (55歳 $\sim$ ).

現病歴: 平成12年 3 月 23 日, 発熱と左側腹部痛が出 現し，近医を受診した．抗生剤投与にて経過観察とな るも, 3 月27日, 腹痛增強し歩行障害を伴うため当院 紹介となった.

入院時現症：身長 $153 \mathrm{~cm}$, 体 重 $53 \mathrm{~kg}$, 血圧 $132 / 70$ $\mathrm{mmHg}$, 脈拍 $68 /$ 分, 体温 $37.5^{\circ} \mathrm{C}$. 左下腹部に圧痛と反 跳痛を認めた. 左股関節屈曲障害による歩行障害を認 めた。

2001年10月 2 日受付 2001 年11月15日採用 〈所属施設住所〉

T444-8553 岡崎市高隆寺町字五所合 3-1
入院時検査所見：血液検查では，白血球数は $10,400 /$ $\mu 1$ と上昇し, 軽度の肝機能障害を䜑めた. CRP は23.5 $\mathrm{mg} / \mathrm{dl}$ と著明に上昇し, 血糖值は $169 \mathrm{mg} / \mathrm{dl}$ と高值で あった(表 1 )。

腹部単純 $\mathbf{X}$ 線写真所見：骨盤毞に小腸ガスを認め た (図 1).

腹部 CT 検査：左骨盤側壁に径約 $4 \mathrm{~cm}$ 大で S 状結 腸に接し，内部に液体と空気による鏡面を形成する襄 胞性腫瘤を認めた。なお，腹腔内遊離ガス像は認めな かった (図 2).

\section{表 1 来院時血液検查所見}

\begin{tabular}{llllll}
\hline WBC & 10.400 & $/ \mu 1$ & $\mathrm{BUN}$ & 11 & $\mathrm{mg} / \mathrm{dl}$ \\
$\mathrm{RBC}$ & $362 \times 10^{4}$ & $/ \mu \mathrm{l}$ & $\mathrm{Cr}$ & 0.64 & $\mathrm{mg} / \mathrm{dl}$ \\
$\mathrm{Hb}$ & 11.2 & $\mathrm{~g} / \mathrm{dl}$ & $\mathrm{AMY}$ & 260 & $\mathrm{IU} / \mathrm{l}$ \\
$\mathrm{Ht}$ & 32.9 & $\%$ & $\mathrm{Glu}$ & 169 & $\mathrm{mg} / \mathrm{dl}$ \\
$\mathrm{Plt}$ & $14.2 \times 10^{4}$ & $/ \mu 1$ & $\mathrm{Na}$ & 137 & $\mathrm{mmol} / \mathrm{l}$ \\
& & & $\mathrm{K}$ & 3.6 & $\mathrm{mmol} / 1$ \\
$\mathrm{TP}$ & 7.7 & $\mathrm{~g} / \mathrm{dl}$ & $\mathrm{Cl}$ & 104 & $\mathrm{mmol} / 1$ \\
$\mathrm{Alb}$ & 4.1 & $\mathrm{~g} / \mathrm{dl}$ & $\mathrm{CRP}$ & 23.5 & $\mathrm{mg} / \mathrm{dl}$ \\
$\mathrm{TB}$ & 1.0 & $\mathrm{mg} / \mathrm{dl}$ & & & \\
$\mathrm{GOT}$ & 41 & $\mathrm{IU} / 1$ & $\mathrm{PT}$ & 76.0 & $\%$ \\
$\mathrm{GPT}$ & 35 & $\mathrm{IU} / 1$ & $\mathrm{APTT}$ & 35.2 & $\mathrm{Sec}$ \\
$\mathrm{LDH}$ & 146 & $\mathrm{IU} / \mathrm{l}$ & (対照) & 29.1 & $\mathrm{Sec}$ \\
\hline
\end{tabular}


以上の所見より，S 状結腸想室穿孔による後腹膜䐬 瘍を強く疑し、同日，緊急手術を施行した。

手術所見：中下腹部正中切開にて開腹した。少量の

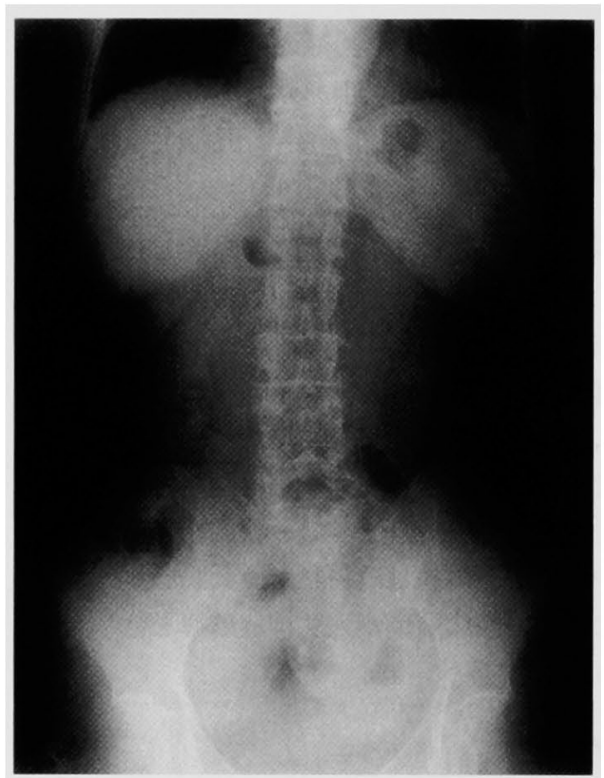

図 1 腹部単純 $\mathrm{X}$ 線写真：骨盤腔に小腸がスを 認めた。
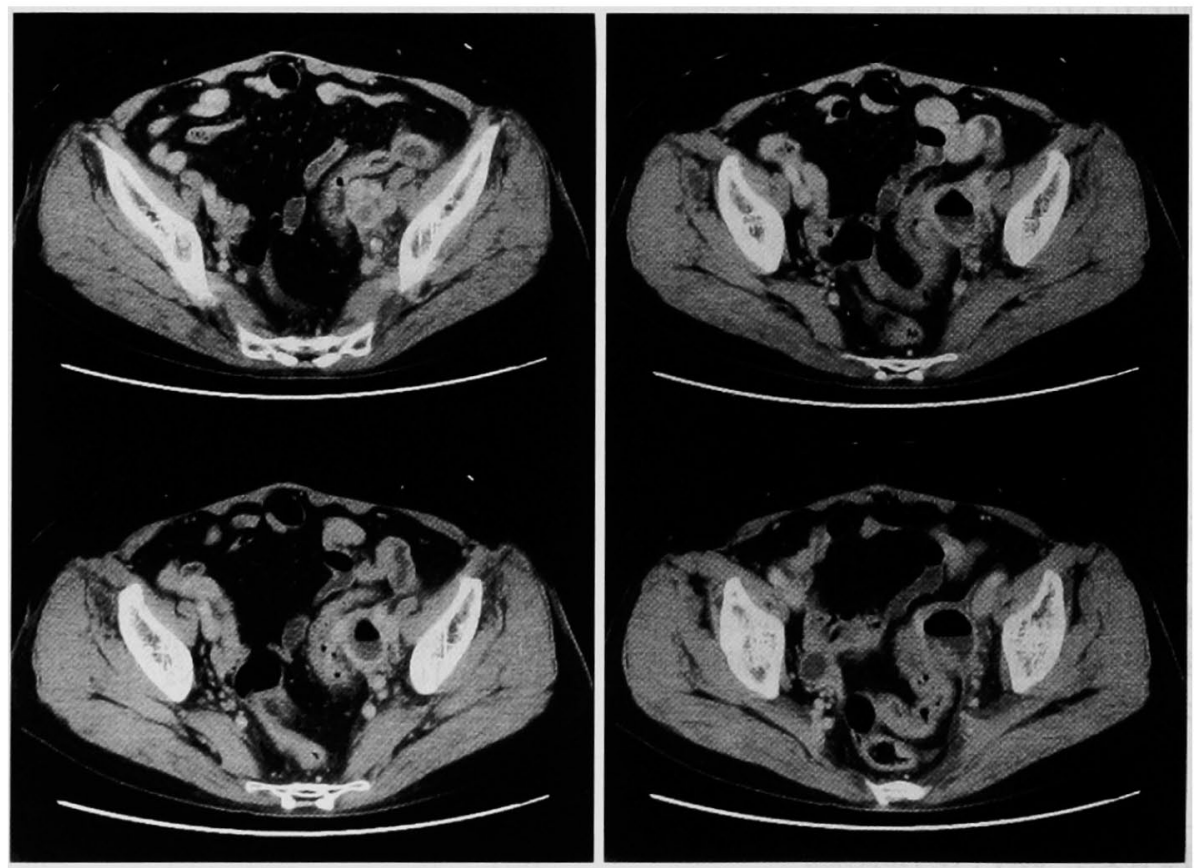

図 2 腹部 CT 検査：左骨盤側壁に $\mathrm{S}$ 状結腸に接し径約 $4 \mathrm{~cm}$ 大の内部に液体と空気による鏡面を 形成する暴胞性腫瘤を認めた。なお，腹腔内遊離ガス像は認めなかった。
腹水をダグラス倣に認めたＳ 状結腸は骨盤左側壁と 炎症性に瘾着しており,周囲は著明な浮腫状であった。 $\mathrm{S}$ 状結腸を遊離すると, 左卵管采, 左内腸骨動静脈周囲 に膿瘍を認めた。澧培養では，E. coli を認めた。 S 状 結腸切除術，腹腔ドレナージ術を施行した。また，炎 症が高度であったため, 横行結腸にて covering colostomyを造設した.

摘出標本所見：S 状結腸粘膜は, 浮腫状であり, 膿 晹は憩室の穿孔部より連続していた。また，他の粘膜 病変は認めなかった（図 3 )。

病理組織学的所見：S 状結腸壁の固有筋層の断裂 と上皮の楩入がありこの部分に穿孔がみられた（図 4). 穿孔部を中心に高度の炎症細胞の浸潤が認められ た (図 5 ). 以上より，S 状結腸憩室穿孔による後腹膜 膿癔と診断された。

術後は, 創感染を認めたが, 速やかに歩行障害は改 善した。第25病日，人工肛門閉鎖術を施行し，第53病 日に退院となった。

\section{考 察}

近年わが国において結腸蒩室症は増加傾向にり，そ の頻度は全注腸造影検査患者の9.4\%にみられるとの 報告もある1. 大腸㮩室の発生部位は, 欧米では S 状結 


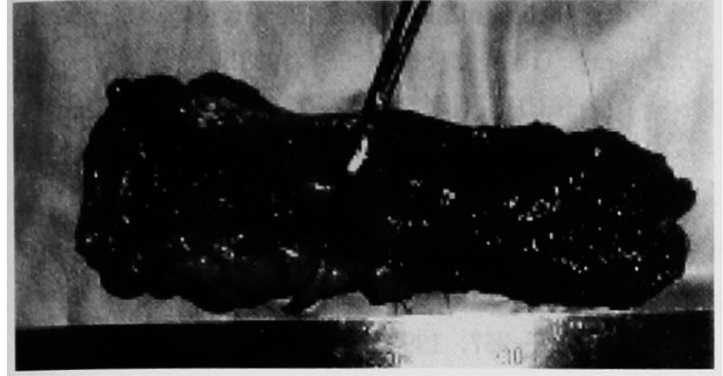

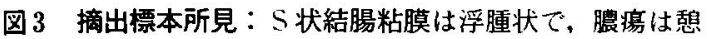
室の穿孔部より連続していた。また, 他の粘膜病変は認め なかった。

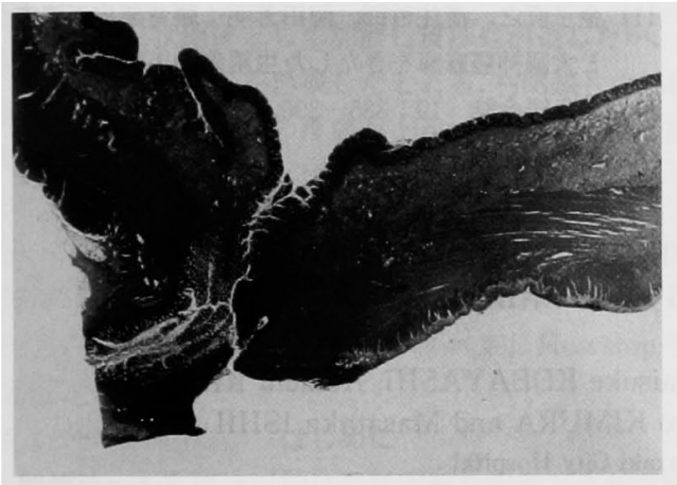

図4 ルーぺ像：S 状結腸壁の固有筋層の断裂と上皮 の陥入がありこの部分に穿孔がみられた（H.E.染 色).

腸を中心とする左側結腸が95\%を占めるのに対し，本 邦では75\%が右側結腸である2).最近は，食事内容の欧 米化につれ左側型の比率が増加している が高くなるほど左側結腸に発生する頻度が增加する傾 向にある ${ }^{3)}$.

大腸㮩室症の合併症としては, 憩室炎, 穿孔, 狭窄, 瘦孔形成，膿瘍形成，出血などがあるが，穿孔は全合 併症中の10〜 40\%とされている゙.また，頽室穿孔例 は，大腸穿孔例全体の $1 / 4$ を占める ${ }^{5}$. 大腸䕀室の穿 孔は，遊離腹腔内に穿孔することが圧倒的に多いか， 鄎室の存在部位によっては，本症例のように後腹膜へ の穿孔例6も報告されている。

内因性疾患による後腹膜膿瘍は比較的稀であるが， その原因として腹腔内臓器の後腹膜穿破が約 $45 \%$, 腎 疾患が約30\%と続いている.前者の具体的疾患として, 結腸䕀室炎, 潰瘍性大腸炎, Crohn 病, 十二指腸潰瘍, 虫垂炎, 結腸癌, 子宮癌などが報告されている781.

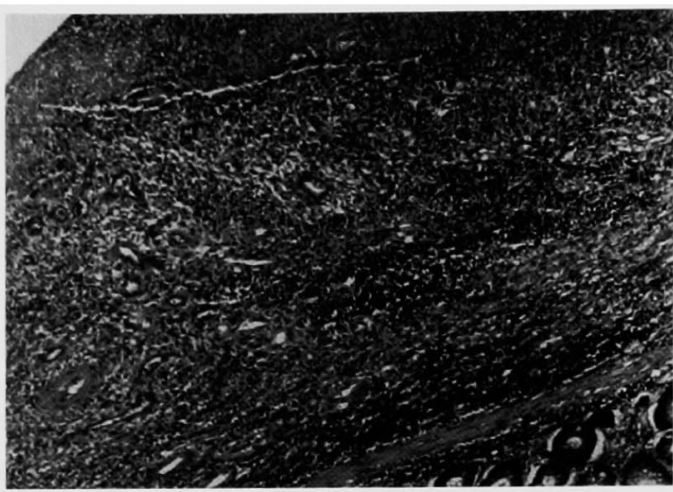

図 5 病理組織所見 (H.E.染色, $\times 40)$ ：穿孔部を中心 に高度の炎症細胞の浸潤が認められた。

後腹膜への消化管穿孔は，症状が非特異的で腹膜刺 激症状が出現しにくいために診断が困難であるが，画 像診断としてCT が有用である゙”。本症例もCTによ り $\mathrm{S}$ 状結腸穿孔による後腹膜膿瘍の確診を得ること ができた。

大腿神経は，第 $2-4$ 腰神経根よりなり，それぞれの 椎間孔を出た後，一束の神経束となり腰筋を外側に向 け横切り，骨盤内では腰筋と腸骨筋の間を下り，鼠径 靶帯下の筋裂孔を通って大腿動脈の外側に沿って恥骨 窝に出る，腸骨裔部では，強勒な腸骨笳膜におおわれ て腸骨筋上を走行しているため骨盤内病変により容易 に絞扼され，絞扼性神経障害がおきる97.

大羪神経麻痺の原因としては, 脊椎疾患と外傷急性 期を除き，後腹膜血腫 $37 \%$ ，感染症 $19 \%$ ，悪性疾患に 直接起因するもの $15^{\circ} \circ$ ，膿瘍などに二次的に起因する もつ $15^{\circ} \%$, 原因不明 $14 \%$ と報告されている ${ }^{101}$. 本症例の 大腿神䅅麻痺は膿癔の増大による絞扼性神経障害と考 えられる。

自験例は，大腿神経麻瘦を合併していたが，われわ れが検索しえた限りでは，大腿神経麻痺を合併した大 腸穿孔による後腹膜膿演は自験例の他に虫垂癌穿孔 例"1を 1 例認めるのみであった。

\section{結語}

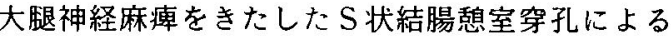
後腹膜膿演の 1 例を経験したりで，若干の文献的考察 を加えて報告した。

本症例は,手術により歩行障害は速やかに改善した。 また,炎症が高度であったので2 期的手術を選択した。 なお, 本論文の要旨は第37回日本腹部救急医学会総会 $($ 札 幌）にて発表した。 


\section{文献}

1）北郷邦昭, 河相開流, 竹内浩紀 他：結腸憩室症と 結腸香室疾患。臨外 $54: 1541-1546,1999$

2）井上幹夫, 吉田 豊, 笹川力地：大腸秝室疾患 の疫学と臨床. 外科 $46: 1003-1010,1984$

3）青木克哲, 西井 博, 小笠原邦夫他：大腸憩室症 手術例の検討。外科 $56: 417-421,1994$

4）佐藤典宏, 上田祐滋, 豊田清一他：大腸俧室穿孔 症例の臨床的検討. 外科 $57: 1341-1345,1995$

5）高瀬 真, 炭山嘉伸，長尾二郎他：大腸穿孔16例 の検討. 日本大腸肛門病会誌 $52 ： 730-735,1999$

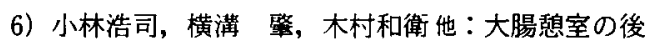
腹膜穿孔の 2 例. 日臨外医会誌 $58: 896-899$, 1997

7) Greca GL, Racalbuto A, Greco L, et al: Retroperitoneal abscess-Rare causes and atypical manifestations: Report of two cases. Surg Today 25 : 965-969, 1995

8) Chern $\mathrm{CH}, \mathrm{Hu} \mathrm{SC}, \mathrm{Kao} W F$, et al : Psoas abscess : Making an early diagnosis in the ED. Am J Emerg Med 15:83-88, 1997

9）田中正道, 富田武史, 宮本隆司 他：私の経験した 骨盤内病変による大腿神経麻㾇の 3 例. 臨整外 $31: 955-957,1996$

10) Apter S, Hertz M, Rubinstein ZJ, et al : Femoral neuropathy : the role of computed tomogra. phy in diagnosis and management in 27 patients. Clin Radiol 40:30-34, 1989

11）金子直之, 清住哲郎, 岡田芳明: 腰背部皮下膿㿋 と大服神経麻疩をきたした虫垂癌の 1 例。日腹部 救急医会誌 $19: 385-390,1999$

\title{
A CASE OF RETROPERITONEAL ABSCESS DUE TO PERFORATION OF THE SIGMOID COLON DIVERTICULUM CAUSING FEMORAL NEUROPATHY
}

\author{
Naohito KANAZUMI, Aya MOTOYAMA, Daisuke KOBAYASHI, Kouichi KATO, \\ Takehiko EGUCHI, Yuichi SUZUKI, Jiro KIMURA and Masataka ISHII \\ Department of Surgery, Okazaki City Hospital
}

We report a rare case of retroperitoneal abscess due to perforation the sigmoid colon diverticulum with femoral neuropathy. A 69-year-old woman admitted for fever, abdominal pain, and difficulty in walking was found on abdominal CT scan to have a $4 \mathrm{~cm}$ retroperitoneal abscess on the left side of the pelvis connected to the sigmoid colon. Emergency surgery based on a diagnosis of a retroperitoneal abscess caused by diverticulum perforation showed the sigmoid colon fixed to the retroperitoneum in the left pelvic space with inflammation and edema. When the sigmoid colon was mobilized anteriorly, a large amount of pus was found. Sigmoidectomy and drainage were done with a covering colostomy because of severe inflammation. The final diagnosis was retroperitoneal abscess caused by diverticulum perforation of the sigmoid colon. The postoperative course was uneventful. The patient could walk smoothly soon after surgery. Perforation of colon diverticula into the retroperitoneal space is thought to be relatively rare, especially retroperitoneal abscess from colon perforation with femoral neuropathy. Our case was the second such report, to our knowledge, in the Japanese literature. 